\title{
Self-Assembled Dextrin Nanogel as Protein Carrier: Controlled Release and Biological Activity of IL-10
}

\author{
Vera Carvalho, ${ }^{1}$ Pedro Castanheira, ${ }^{2}$ Pedro Madureira, ${ }^{3,4}$ Sílvia A. Ferreira, ${ }^{1}$ \\ Carla Costa, ${ }^{5}$ João P. Teixeira, ${ }^{5}$ Carlos Faro, ${ }^{2,6}$ Manuel Vilanova, ${ }^{3,4}$ Miguel Gama ${ }^{1}$ \\ ${ }^{1} \mathrm{IBB}$, Institute for Biotechnology and Bioengineering, Centre of Biological Engineering, \\ Universidade do Minho, Campus de Gualtar, 4710-057 Braga, Portugal; \\ telephone: (+351) 253604 400; fax: (+351) 253678 986; e-mail: fmgama@deb.uminho.pt \\ ${ }^{2}$ Biocant, Molecular Biotechnology Unit, Parque Tecnológico de Cantanhede, Cantanhede, \\ Portugal \\ ${ }^{3}$ ICBAS, Instituto de Ciências Biomédicas de Abel Salazar, Porto, Portugal \\ ${ }^{4}$ IBMC, Instituto de Biologia Molecular e Celular, Porto, Portugal \\ ${ }^{5}$ Environmental Health Department, Portuguese National Institute of Health, Porto, Portugal \\ ${ }^{6}$ Departament of Life Sciences, Universidade de Coimbra, Coimbra, Portugal \\ Received 15 December 2010; revision received 23 February 2011; accepted 28 February 2011 \\ Published online 9 March 2011 in Wiley Online Library (wileyonlinelibrary.com). DOI 10.1002/bit.23125
}

\begin{abstract}
Interleukin-10 (IL-10) is an anti-inflammatory cytokine, which active form is a non-covalent homodimer. Given the potential of IL-10 for application in various medical conditions, it is essential to develop systems for its effective delivery. In previous work, it has been shown that a dextrin nanogel effectively incorporated and stabilized rIL-10, enabling its release over time. In this work, the delivery system based on dextrin nanogels was further analyzed. The biocompatibility of the nanogel was comprehensively analyzed, through cytotoxicity (lactate dehydrogenase (LDH) release, MTS, Live, and Dead) and genotoxicity (comet) assays. The release profile of rIL-10 and its biological activity were evaluated in vivo, using C57BL/6 mice. Although able to maintain a stable concentration of IL-10 for at least $4 \mathrm{~h}$ in mice serum, the amount of protein released was rather low. Despite this, the amount of rIL-10 released from the complex was biologically active inhibiting TNF- $\alpha$ production, in vivo, by LPS-challenged mice. In spite of the significant stabilization achieved using the nanogel, rIL-10 still denatures rather quickly. An additional effort is thus necessary to develop an effective delivery system for this cytokine, able to release active protein over longer periods of time. Nevertheless, the good biocompatibility, the protein stabilization effect and the ability to perform as a carrier with controlled release suggest that self-assembled dextrin nanogels may be useful protein delivery systems.
\end{abstract}

Correspondence to: M. Gama

Contract grant sponsor: Fundação para a Ciência e Tecnologia (FCT), Portugal Contract grant number: SFRH/BD/27359/2006

Contract grant sponsor: FCT

Contract grant number: PTDC/BI0/67160/2006; SUDOE-FEDERIMMUNONETSOE1/P1/ E014
Biotechnol. Bioeng. 2011;108: 1977-1986.

(C) 2011 Wiley Periodicals, Inc.

KEYWORDS: protein delivery system; dextrin nanogel; biocompatibility; interleukin-10; anti-inflammatory agent

\section{Introduction}

Interleukin-10 (IL-10) is produced by various cell types including $\mathrm{T}$ and $\mathrm{B}$ cells, monocytes, and macrophages (Moore et al., 2001; Pestka et al., 2004). This cytokine is highly pleiotropic displaying biological activities that include: inhibition of several cytokines synthesis, including IL-1, IL-2, IL-3, IL-6, IL-8, IL-12, tumor necrosis factor $\alpha$ (TNF- $\alpha$ ), and interferon $\gamma$ (de Waal Malefyt et al., 1991a); immunosuppressive effects on monocytes/macrophages (Bogdan et al., 1991; Fiorentino et al., 1991; Gazzinelli et al., 1992); as well as immunostimulatory activity on a broad range of cell types, including $\mathrm{T}$ cells (MacNeil et al., 1990), B cells (Defrance et al., 1992), and mast cells. Furthermore, IL-10 down-regulates constitutive and IFN- $\gamma$ or IL-4-induced class II major histocompatibility complex molecules expression on monocytes, dendritic cells, and Langerhans cells (de Waal Malefyt et al., 1991b; Groux et al., 1998) as well as adhesion and co-stimulatory molecules on antigen-presenting cells (Creery et al., 1996; Willems et al., 1994). It also suppresses the release of reactive oxygen 
intermediates (Bogdan et al., 1991; Fiorentino et al., 1991). IL-10 has thus a strong anti-inflammatory activity, acting as a general suppressive factor of immune responses. It might be therefore an effective agent to prevent LPS toxicity in vivo, as previously demonstrated in mice (Gerard et al., 1993; Howard et al., 1993; Leon et al., 1999).

Due to its immunoregulatory properties, this cytokine has been proposed to be used in vaccination (Berzofsky et al., 2001) or in the treatment of allergies (Pullerits, 2002), infectious diseases (Hubel et al., 2002), acute and chronic inflammatory diseases (Asadullah et al., 2003), among pathologic conditions. Usually, proteins of this kind are expensive to produce on a large scale and denature easily, loosing their bioactivity, thus having a quite short half-life in vivo. So, it is essential to develop new delivery systems that would allow effective therapeutic effects at a minimum dosage. A promising method is protein encapsulation by polymeric nanogels (or hydrogel nanoparticles), which, by trapping them in a hydrated polymer-network, minimize denaturation, enabling slow-release, while maintaining an effective concentration for the necessary period of time (Kim et al., 2009; Leonard et al., 2004; Murthy et al., 2002, 2003).

In previous work (Carvalho et al., 2010), a dextrin selfassembled nanogel was used to effectively incorporate a recombinant biologically active mutated murine IL-10 form (rIL-10) and shown to enable its release over time. In this work, we present a further characterization of the complex nanogel/rIL-10, including the nanogel's cellular cytotoxicity and the in vivo rIL-10 release from the nanogel complex, after subcutaneous (sc) injection in C57BL/6 mice. The effect of rIL-10 and nanogel/rIL-10 administration before lipopolysaccharide (LPS) challenge (endotoxin-induced shock) in C57BL/6 mice, assessed by systemic TNF- $\alpha$ release, was also analyzed.

\section{Material and Methods}

All reagents used were of laboratory grade and purchased from Sigma-Aldrich (MO), unless stated otherwise. IL-10 and TNF- $\alpha$ were quantified by a enzyme-linked immunosorbent assay (ELISA) commercial kit, Mouse IL-10 ELISA Ready-SET-Go! and Mouse TNF-a ELISA Ready-SET-Go! (eBioscience, San Diego, CA, USA), respectively, following the manufacturer's instructions.

\section{Preparation of Nanogel and Complex Nanogel/rIL-10}

Dextrin nanogel and the complex nanogel/rIL-10 were prepared as previously described (Carvalho et al., 2010). Briefly, the self-assembled nanogels were obtained by dissolving the lyophilized dextrin-VMA-SC ${ }_{16}$ in cell culture medium or phosphate-buffered saline (PBS) $\mathrm{pH} \quad 7.4$ $\left(2.7 \mathrm{mM} \mathrm{KCl}, 137 \mathrm{mM} \mathrm{NaCl}, 10 \mathrm{mM} \mathrm{HPO}_{4} \cdot 2 \mathrm{H}_{2} \mathrm{O}\right.$, $2 \mathrm{mM} \mathrm{KH}_{2} \mathrm{PO}_{4}$ ), at a concentration of $1.0 \mathrm{mg} / \mathrm{mL}$. The dissolution was accomplished after approximately $16 \mathrm{~h}$ at room temperature, with stirring. The nanogel formation was confirmed by dynamic light scattering (DLS), as described previously (Carvalho et al., 2010; Goncalves and Gama, 2008; Goncalves et al., 2007, 2010). The concentration was adjusted to $0.4,0.1$, and $0.05 \mathrm{mg} / \mathrm{mL}$ by dilution of the $1 \mathrm{mg} /$ $\mathrm{mL}$ suspension.

The complex nanogel/rIL-10 was formed by dissolving rIL-10 in cell culture medium or PBS, followed by dissolution of lyophilized dextrin-VMA-SC 16 , for approximately $16 \mathrm{~h}$ at room temperature with stirring. The rIL-10 incorporation was confirmed by quantifying the amount of rIL-10 free in solution using the ELISA commercial kit, following the manufacturer's instructions.

All suspensions were sterilized by filtration through a $0.45 \mu \mathrm{m}$ membrane.

\section{Cell Cultivation}

\section{Mouse Embryo Fibroblasts 3T3}

Mouse embryo fibroblasts 3T3 (ATCC CCL-164) were grown in Dulbecco's modified Eagle's medium supplemented with $10 \%$ newborn calf serum (Invitrogen, CA) and $1 \mu \mathrm{g} / \mathrm{mL}$ penicillin/streptavidin (DMEM complete medium [cDMEM]) at $37^{\circ} \mathrm{C}$ in a $95 \%$ humidified air containing $5 \%$ $\mathrm{CO}_{2}$. At $80 \%$ confluency, 3T3 fibroblasts were harvested with $0.05 \%(\mathrm{w} / \mathrm{v})$ trypsin-EDTA and subcultivated in the same medium.

\section{Murine Bone Marrow-Derived Macrophages (BMDM)}

Macrophages were obtained from mouse bone marrow as follows: mice were sacrificed and femurs and tibias removed under aseptic conditions. Bones were flushed with Hanks' balanced salt solution. The resulting cell suspension was centrifuged at $500 \times g$ and resuspended in RPMI 1640 medium supplemented with $10 \mathrm{mM}$ HEPES, 10\% heatinactivated fetal bovine serum (FBS), $60 \mu \mathrm{g} / \mathrm{mL}$ penicillin/ streptavidin, $0.005 \mathrm{mM} \beta$-mercaptoethanol (RPMI complete medium [cRPMI]), and 10\% L929 cell conditioned medium (LCCM). To remove fibroblasts or already differentiated macrophages, cells were cultured, on cell culture dishes (Sarstedt, Canada), overnight at $37^{\circ} \mathrm{C}$ in a $5 \%$ $\mathrm{CO}_{2}$ atmosphere. Then, non-adherent cells were collected with warm cRPMI, centrifuged at $500 \times g$, distributed in 96well plates (Sarstedt, Canada) at a density of $1 \times 10^{5}$ cells/ well, and incubated at $37^{\circ} \mathrm{C}$ in a $5 \% \mathrm{CO}_{2}$ atmosphere. Four days after seeding, $10 \%$ of LCCM was added, and the medium was renewed on the seventh day. After 10 days in culture, cells were completely differentiated into macrophages. This method allows for the differentiation of a homogenous primary culture of macrophages that retain the morphological, physiological, and surface markers characteristics of these phagocytic cells (Mosmann, 1983; Tushinski et al., 1982; Zhang et al., 2008).

\section{Evaluation of Nanogel Cellular Cytotoxicity}

Cellular cytotoxicity was assessed using the MTS, live and dead, and comet assays, and by measuring the release of LDH. Although all these methods are usually used to 
evaluate cell viability, they address different features, namely the cell integrity or metabolic activity. In our experience, using the different methods allows a more comprehensive and consistent detection of cytotoxicity.

Mouse embryo fibroblasts $3 \mathrm{~T} 3$ were seeded $\left(4 \times 10^{5}\right.$ cells/ well in a 96-well polystyrene plate or $1 \times 10^{6}$ cells/well in a six-well polystyrene plate) and incubated at $37^{\circ} \mathrm{C}, 5 \% \mathrm{CO}_{2}$ for $2 \mathrm{~h}$. Then, the culture medium was removed and replaced with cDMEM containing a different concentration of nanogel suspension $(0.05-1 \mathrm{mg} / \mathrm{mL})$ and cells further incubated for 24 or $48 \mathrm{~h}$. In a similar way, on the tenth day of BMDM differentiation, the culture medium was replaced with NPs suspensions $(0.05-1 \mathrm{mg} / \mathrm{mL})$, in cRPMI, and cells further incubated for 24 or $48 \mathrm{~h}$. Control cells were incubated with fresh medium and wells containing only growth medium were used as blanks.

Exceptionally, the culture medium used for the LDH release assay had only $1 \%$ serum and the incubation times were three and $20 \mathrm{~h}$.

All assays were made with triplicate cell incubations.

\section{MTS Assay}

Cellular viability, was assessed by measuring cell concentration via mitochondrial reduction of the tetrazolium salt MTS (3-(4,5-dimethyl-2-yl)-5-(3-carboxy-methoxyphenyl)-2(4-sulfophenyl)-2H-tetrazolium) in the presence of $5 \%$ phenazinemethosulfate over a $1 \mathrm{~h}$ incubation period. The colored reaction product formazan is soluble in the culture medium and can be measured spectrophotometrically at a wavelength of $490 \mathrm{~nm}$ with a reference wavelength of $570 \mathrm{~nm}$.

After the incubation time, the culture medium of each well was replaced with $100 \mu \mathrm{L}$ of fresh culture medium and $20 \mu \mathrm{L}$ of CellTiter $96^{\circledR}$ AQueous One Solution Reagent (Promega, CA) was added and the plate further incubated for $1 \mathrm{~h}$ at $37^{\circ} \mathrm{C}, 5 \% \mathrm{CO}_{2}$, as indicated by the manufacturer. The amount of soluble formazan produced by cellular reduction of MTS was measured at $490 \mathrm{~nm}$.

\section{Live and Dead Assay}

The LIVE/DEAD ${ }^{\circledR}$ Viability/Cytotoxicity Kit for mammalian cells (Invitrogen, CA) was used to determine cell viability. This kit provides two-color fluorescence cell viability assay, based on the simultaneous determination of live and dead cells with two probes that measure intracellular esterase activity and plasma membrane integrity.

Briefly, after the incubation time, $200 \mu \mathrm{L}$ of a $2 \mu \mathrm{M}$ calcein AM solution and $4 \mu \mathrm{M}$ ethidium homodimer-1, in sterile PBS, were added to the wells, incubated for 30 to $45 \mathrm{~min}$ at $37^{\circ} \mathrm{C}, 5 \% \mathrm{CO}_{2}$ (as indicated by the manufacturer) and visualized in a fluorescence microscope.

\section{Lactate Dehydrogenase Release}

The Cytotoxicity Detection Kit ${ }^{\text {PLUS }}$ (LDH) (Roche, Basel, Switzerland) is a colorimetric assay for quantitating cytotoxicity/cytolysis by measuring $\mathrm{LDH}$ activity released from damaged cells.
The amount of LDH released was measured using the Cytotoxicity Detection $\mathrm{Kit}^{\mathrm{PLUS}}(\mathrm{LDH})$ following manufacturer's instructions. In few words, after cell incubation with nanogel, $100 \mu \mathrm{L}$ of reaction mixture was added to each well and the plate incubated at room temperature for $9 \mathrm{~min}$, in the dark. Then, $50 \mu \mathrm{L}$ of stop solution was added to each well and the absorbance of the samples was measured at $492 \mathrm{~nm}$. Three controls were included: background control (determines the LDH activity in the assay medium) made with $1 \%$ serum culture medium; low control (determines the LDH activity released from the untreated normal cells) made with cells incubated with $1 \%$ serum culture medium; and, high control (determines the maximum releasable $\mathrm{LDH}$ activity in the cells) made with cells incubated with $1 \%$ serum culture medium where $5 \mu \mathrm{L}$ of lysis solution was added before LDH quantification.

To determine the percentage cytotoxicity, the average absorbance values of the triplicate samples and controls were calculated; the average absorbance value obtained in the background control was subtracted to the value obtained using the samples. Cytotoxicity percentage values were obtained substituting the resulting values in the following equation:

Cytotoxicity $(\%)=\frac{(\text { Sample value }- \text { Low control })}{(\text { High control }- \text { Low control })} \times 100$

\section{Comet Assay}

The comet assay (single-cell gel electrophoresis) is a simple method for detecting DNA damage at the level of individual cells (Singh et al., 1988). Cells embedded in agarose on a microscope slide are lysed with detergent and high salt to form nucleiods containing supercoiled loops of DNA linked to the nuclear matrix. Electrophoresis at high $\mathrm{pH}$ results in structures resembling comets, observed by fluorescence microscopy; the intensity of the comet tail relative to the head reflects the number of DNA breaks.

The comet assay was performed as described by Costa et al. (2008), with some exceptions. Briefly, collected cells were centrifuged $(7500 \times g$ for $3 \mathrm{~min})$, suspended in $100 \mu \mathrm{L}$ of $0.6 \%$ low-melting-point agarose in PBS and dropped onto a slide precoated with a layer of $1 \%$ normal melting point agarose and covered with coverslips. Slides were placed on ice and allowed to solidify. Cover slips were then removed and slides were immersed in freshly prepared lysing solution $\left(2.5 \mathrm{M} \mathrm{NaCl}, 100 \mathrm{mM} \mathrm{Na}_{2}\right.$ EDTA, $10 \mathrm{mM}$ TrisBase, $0.25 \mathrm{M} \mathrm{NaOH}, \mathrm{pH} 10$ ) for $1 \mathrm{~h}$ at $4{ }^{\circ} \mathrm{C}$, in the dark. After lyses, slides were placed on a horizontal electrophoresis tank and the tank filled with freshly made alkaline electrophoresis solution ( $1 \mathrm{mM} \mathrm{Na}_{2}$ EDTA, $300 \mathrm{mM} \mathrm{NaOH}$, pH 13) to cover the slides, and left for $20 \mathrm{~min}$ in the dark to allow DNA unwinding and alkali-labile site expression. Then, electrophoresis was carried out for $20 \mathrm{~min}$ at $30 \mathrm{~V}$ and $300 \mathrm{~mA}$ $(1.13 \mathrm{~V} / \mathrm{cm})$ and after, the slides were washed for $10 \mathrm{~min}$ with neutralizing solution (0.4 M TrisBase, $\mathrm{pH} 7.5)$. After 
neutralization, the slides were left to dry overnight in the dark. Afterwards, the slides were rehydrated for $30 \mathrm{~min}$ with ice-cold bidistilled water and stained with ethidium bromide solution $(20 \mathrm{~g} / \mathrm{mL})$ for $20 \mathrm{~min}$. After staining, the slides were washed again twice with ice-cold bidistilled water for 20 min. Each experimental condition was carried out twice with mousse embryo fibroblasts 3T3 and once with BMDM, and one slide was prepared for each sample. A "blind" scorer examined 100 randomly selected cells in each slide using a magnification of $500 \times$. The DNA damages were evaluated by image analysis performed with Comet Assay IV software (Perceptive Instruments, Haverhill, UK). Data collected from each cell included tail length (TL), tail intensity, and tail moment.

\section{In vivo rIL-10 Release From the Nanogel/rlL-10}

C57BL/6 mice were purchased from Charles River Laboratories España S. A. (Spain).

Mice were injected with $200 \mu \mathrm{L}$ of nanogel/rIL-10 suspension in PBS $(12.5 \mu \mathrm{g} / \mathrm{mL}$ rIL-10 and $5 \mathrm{mg} / \mathrm{mL}$ nanogel), rIL-10 solution in PBS $(12.5 \mu \mathrm{g} / \mathrm{mL})$, nanogel suspension in PBS $(5 \mathrm{mg} / \mathrm{mL})$, or PBS via subcutaneous (sc) route. Blood samples were taken at given intervals of time and serum concentrations of IL-10 were assayed by ELISA.

\section{In vivo Effects of rlL-10 and Nanogel/rIL-10 in Endotoxin-Induced Shock Mice}

C57BL/6 mice were injected intraperitoneally (i.p.) with $100 \mu \mathrm{g}$ of LPS $30 \mathrm{~min}$ after an i.p. administration of rIL-10 $(2.5 \mu \mathrm{g})$, nanogel/rIL-10 (1 mg nanogel, $2.5 \mu \mathrm{g}$ rIL-10), and nanogel $(1 \mathrm{mg})$. Serum TNF- $\alpha$ levels were determined by ELISA 1.5 and $6 \mathrm{~h}$ after LPS challenge. As controls, serum TNF- $\alpha$ levels were determined, in mice injected with PBS with and without LPS challenge.

\section{Data Analysis}

Data are presented as means \pm SD of the indicated number $(n)$ of determinations. Statistical analysis was performed using the variance analysis method (One way ANOVA). Significant differences between samples were determined through Dunnet Test.

\section{Results and Discussion}

\section{Nanogel Cellular Cytotoxicity Assays}

Polymer formulations, including polymer-protein conjugates, are finding increasing clinical use. Synthetic and natural polymers have been explored as drug carriers, but many of the polymers used clinically are still nonbiodegradable synthetic polymers (Hreczuk-Hirst et al., 2001). The proven clinical tolerability of dextrin and readily degradation by amylases suggest that this polymer might be ideal for the development of drug carriers (Hreczuk-Hirst et al., 2001). Furthermore, dextrin is readily excreted due to its low molecular weight, hence accumulation in the tissues is unlikely. In this work, dextrin is used to produce selfassembled nanogels following methodologies described in previous work (Carvalho et al., 2010; Goncalves and Gama, 2008; Goncalves et al., 2007, 2010).

Self-assembled dextrin nanogels, dispersed in water at a concentration of $1.0 \mathrm{mg} / \mathrm{mL}$, were observed using DLS after filtration through a $0.45 \mu \mathrm{m}$ membrane. The DLS analysis, in the intensity distribution, revealed two populations with roughly 25 and $150 \mathrm{~nm}$ (Goncalves and Gama 2008; Goncalves et al., 2007). The conversion to number distribution highlighted only the smaller population of particles, the predominant one. The $z$-value obtained was $23.6 \mathrm{~nm}$, representative of the average size of polydisperse colloids. Previously (Goncalves and Gama 2008), the variation of the hydrodynamic diameter ( $z$-value) and zeta-potential of the nanogel with $\mathrm{pH}$ was studied and found to be almost constant and close to zero. Although the low zeta potential, the nanogel is stable. The stability observed in a wide range of conditions (the effect of ionic force, $\mathrm{pH}$, and presence of urea were analyzed and reported elsewhere), can be attributed to the solvation forces (Goncalves and Gama 2008). Indeed, in the absence of electrostatic repulsive forces, the colloidal stability may be assigned either to steric effects, to hydration forces, or the both, counteracting the attractive van der Waals forces (Fichthorn and Qin, 2006).

In order to evaluate the biocompatibility of the dextrin nanogel, in vitro experiments were carried out using mouse embryo fibroblasts 3T3 and bone marrow derived macrophages (BMDM). Cytotoxicity, defined as the "in vitro evaluation of toxicological risks using cell culture," is a way to assess the in vitro biocompatibility of materials to be used in biomedical applications. Biocompatibility assays deal with the assessment of various aspects of cellular function such as cell viability and proliferation, loss of membrane integrity, reduced cell adhesion, biosynthetic activity, and altered cell morphology (Chiellini et al., 2006). Moreover, the information gained from these types of investigations may be used in the design of further in vivo experiments. Given the concerns related to the possible toxicity associated to nanoparticulated materials, we found appropriate to perform a comprehensive characterization of biocompatibility of the nanogel. In this case we address the cytotoxicity and genotoxicity analysis.

Nanogel was resuspended in culture medium at different concentrations ranging between 0.05 and $1 \mathrm{mg} / \mathrm{mL}$. Cells were incubated for 24 or $48 \mathrm{~h}$ with the nanogel suspensions and then tested for cell viability and proliferation using MTS, LDH, Comet, and Live and Dead assays. It should be noted that the higher concentration used was intentionally high, as to detect any possible effects caused to the cells by the nanogel, it must be acknowledged however that such a concentration is not likely to be reached in any biomedical application of the material. 
Figure 1A illustrates the MTS absorbance values obtained for fibroblasts cultured with the nanogel. Fibroblasts in control wells (wells with cDMEM without nanogel) behave as expected: the cells adhere after seeding and proliferate, reaching confluency after $48 \mathrm{~h}$. In wells with the higher concentration of the nanogel $(1 \mathrm{mg} / \mathrm{mL})$, cell proliferation is inhibited, especially after $48 \mathrm{~h}$ incubation. In wells treated with 0.1 and $0.05 \mathrm{mg} / \mathrm{mL}$, cells proliferate normally and also reach confluency after $48 \mathrm{~h}$.

MTS was also used to evaluate BMDM cells viability (Fig. 1B). In control wells (with cRPMI), the number of cells is relatively constant over time meaning that cells are kept alive. As seen with fibroblasts, after $48 \mathrm{~h}$, the absorbance values are very low in wells treated with the higher concentration of the nanogel, meaning that cells die to a significant extent after $48 \mathrm{~h}$ of incubation. Cells treated with the lower concentrations $(0.1$ and $0.05 \mathrm{mg} / \mathrm{mL})$ show a behavior similar to control wells.

To further evaluate the nanogel cytotoxicity, the Live and Dead $^{\mathbb{R}}$ assay was performed using the nanogel in concentrations ranging from 0.1 to $1 \mathrm{mg} / \mathrm{mL}$. In Figure 2, fluorescence images of BMDM cells, after 24 or $48 \mathrm{~h}$ incubation with the nanogel are shown. In wells with cRPMI (control wells) the number of living cells (stained in green) is far superior to the number of dead cells (stained in red) and this proportion is maintained over time. When cells are treated with $1 \mathrm{mg} / \mathrm{mL}$ of the nanogel, the number of cells stained in red augments, especially after $48 \mathrm{~h}$ incubation. Lower concentrations of the nanogel did not alter significantly the number of living cells comparatively to control wells and the number of green live cells is fairly the same over time. Similar results were obtained using mouse embryo fibroblasts 3T3 (images not shown).

Table I reports the percentage of the nanogel cytotoxicity in mouse embryo fibroblasts 3T3 and BMDM, measured by the LDH activity released from damaged cells.

In agreement with the previous results, $1 \mathrm{mg} / \mathrm{mL}$ of the nanogel showed higher toxicity toward fibroblasts. After $20 \mathrm{~h}$ incubation, 0.1 and $0.05 \mathrm{mg} / \mathrm{mL}$ of the nanogel did not show any cytotoxicity. Cytotoxicity was also measured in BMDM cultures by measuring LDH activity released from damaged cells (Table I) and confirmed the previous results.

The genotoxicity of a material may be measured by analyzing the damage caused on DNA. The comet assay or single-cell gel electrophoresis assay is a rapid, sensitive and relatively simple procedure to detect DNA damage (Singh et al., 1988). It combines the simplicity of biochemical techniques for detecting DNA single strand breaks (strand breaks and incomplete excision repair sites), alkali-labile sites and cross-linking, using the single cell approach. The advantages of the comet assay, relative to other genotoxicity tests, include its high sensitivity for detecting low levels of both single and double stranded breaks in damaged DNA, the requirement for small numbers of cells per sample, flexibility, low cost, and ease of application (BrendlerSchwaab et al., 2005; Collins et al., 1997, 2008). Moreover, the comet assay is arguably one of the most widely used tests for genotoxicity available (Anderson and Plewa 1998; Anderson et al., 1998), being already described as a reproducible assay to evaluate nanoparticles genotoxicity (Collins et al., 1997), and suggested as a diagnostic tool for clinical management of cancer (Collins et al., 2008). The genotoxicity of a nanomaterial may result from a direct interaction with DNA, or from an indirect response caused by several factors, including surface stress through direct particle influences on DNA, the release of toxic ions from soluble nanoparticles, or generation of oxidative stress (Barnes et al., 2008).

The comet assay is based on the ability of negatively charged loops/fragments of DNA to be drawn through an agarose gel, in response to an electric field. The extent of DNA migration depends directly on the DNA damage present in the cells (Collins et al., 2008). It should be pointed out that DNA lesions consisting of strand breaks after treatment with alkali, either alone or in combination with certain enzymes (as endonucleases) increases DNA migration, whereas DNA-DNA and DNA-protein cross-links result in retarded DNA migration compared to those in
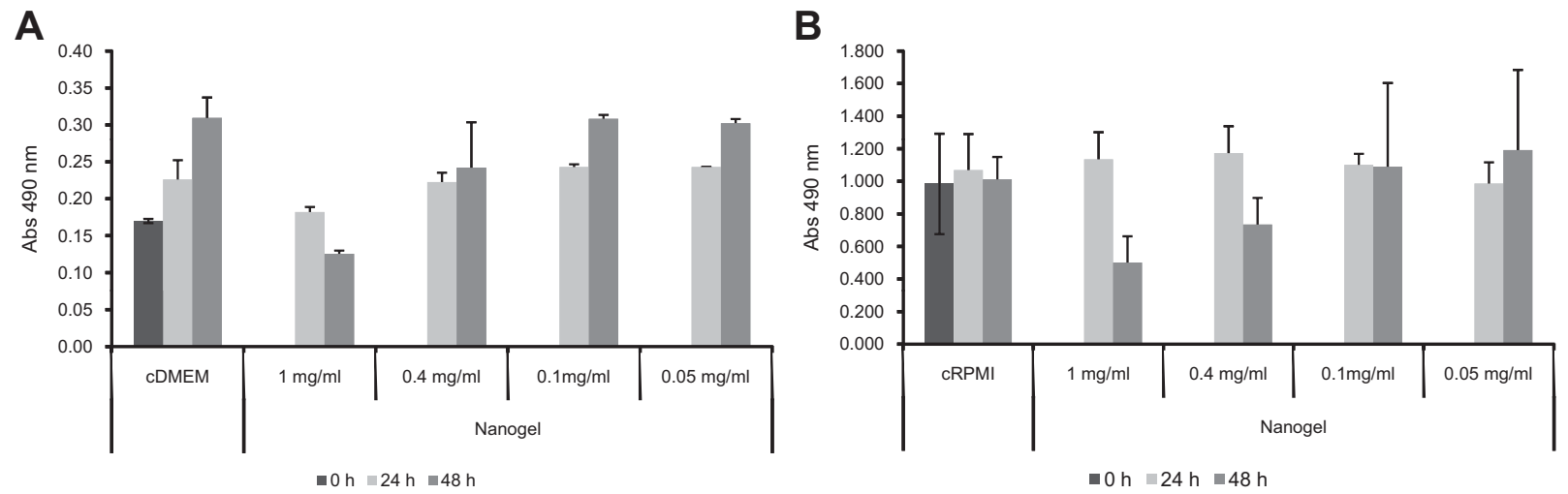

Figure 1. MTS absorbance results. A: Nanogel incubation with mouse embryo fibroblasts $3 T 3$ and (B) nanogel incubation with $B M D M$. Shown are mean \pm SD values $(n=3)$. 
CRPMI

24 hours

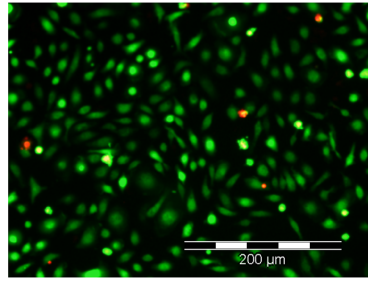

48 hours

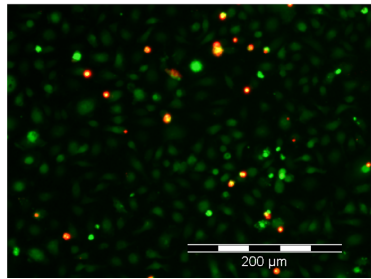

$1 \mathrm{mg} / \mathrm{ml}$ Nanogel
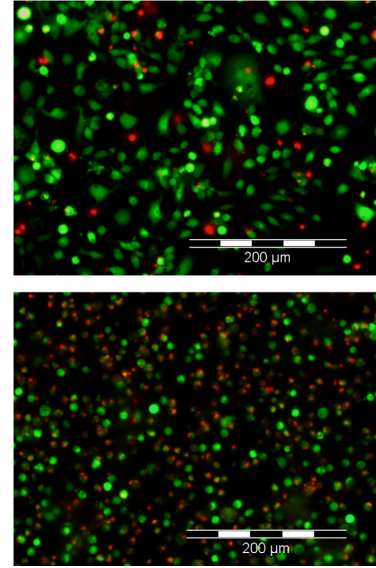

$0.4 \mathrm{mg} / \mathrm{ml} \mathrm{Nanogel}$
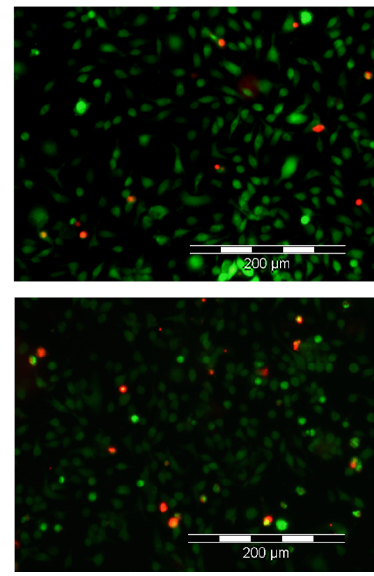

$0.1 \mathrm{mg} / \mathrm{ml}$ Nanogel

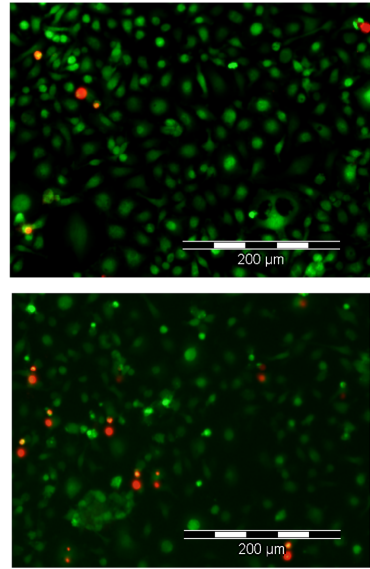

Figure 2. Fluorescence photographs of $B M D M$ cells incubated with the nanogel $(0.1-1 \mathrm{mg} / \mathrm{mL})$ stained with LIVE/DEAD ${ }^{\mathbb{R}}$ Viability/Cytotoxicity Kit for mammalian cells. Live cells are stained in green and dead cells stained in red. [Color figure can be seen in the online version of this article, available at http://wileyonlinelibrary.com/bit]

concurrent controls (Tice et al., 2000). In the procedure described, a suspension of cells, previously treated with different concentrations of the nanogel, was mixed with low melting agarose and spread in slides precoated with normal melting point agarose. After lysis of cells with detergent at high salt concentration, DNA unwinding and electrophoresis was carried out specifically at pH 13 (Miyamae et al., 1997). When an electric field is applied, the DNA migrates out of the cell, in the direction of the anode, looking like a comet. The size and shape of the comet is related with the extent of the DNA damage (Fairbairn et al., 1995).

Although information on different comet assay parameters has been collected, data presented here concerns only TL as this was the parameter that offered the more reproducible results in duplicates.

Results show that DNA damage assessed by means of TL increases with concentration and time of exposure to nanogel in both studied cell types (3T3 fibroblasts and BMDM). Figure 3 presents observed means of TL in each experimental condition.

Table I. Nanogel cytotoxicity in mouse embryo fibroblasts 3T3 and BMDM, evaluated by Cytotoxicity Detection Kit ${ }^{\text {PLUS }}$ (LDH).

\begin{tabular}{lccccc}
\hline & \multicolumn{4}{c}{ Cytotoxicity (\%) \pm SD (\%) } \\
\cline { 2 - 3 } \cline { 5 - 6 } $\begin{array}{l}\text { Nanogel } \\
(\mathrm{mg} / \mathrm{mL})\end{array}$ & \multicolumn{2}{c}{$3 \mathrm{~h}$} & & \multicolumn{2}{c}{$20 \mathrm{~h}$} \\
\cline { 2 - 3 } \cline { 5 - 6 } & $3 \mathrm{~T} 3$ fibroblasts & BMDM & & $3 \mathrm{~T} 3$ fibroblasts & BMDM \\
\hline 1 & $9.9 \pm 4$ & $0.5 \pm 0$ & & $39.8 \pm 15$ & $6.5 \pm 3$ \\
0.4 & $2.8 \pm 2$ & $\mathrm{ND}$ & & $15 \pm 5$ & $\mathrm{ND}$ \\
0.1 & $\mathrm{ND}$ & $\mathrm{ND}$ & & $\mathrm{ND}$ & $\mathrm{ND}$ \\
0.05 & $\mathrm{ND}$ & $\mathrm{ND}$ & & $\mathrm{ND}$ & $\mathrm{ND}$ \\
\hline
\end{tabular}

Cytotoxycity percentage values where obtained as described in the experimental section. Values shown correspond to mean $\pm \mathrm{SD}(n=3)$.

$\mathrm{ND}$, not detected.
The overall obtained results indicate a high level of cytocompatibility for the lower concentrations of the nanogel $(0.1$ and $0.05 \mathrm{mg} / \mathrm{mL})$, under the conditions tested and for the two cell lines used. The results obtained with the higher concentrations, especially $1 \mathrm{mg} / \mathrm{mL}$, indicated that, in the assays conditions, nanogel can present moderate cytotoxicity, inhibiting mouse embryo 3T3 fibroblasts proliferation and diminishing BMDM viability, although no significant DNA damages were detected.

\section{In vivo Release and Biological Activity of rIL-10}

Aiming at achieving an effective protein delivery in vivo, carriers such as liposomes, polymer micelles, and micro or nanogels have been developed (Branco and Schneider, 2009; Devalapally et al., 2007; Haag and Kratz, 2006; Kim et al., 2009; Lukyanov and Torchilin, 2004; Nair and Laurencin, 2006; Nayak and Lyon, 2005). Among them, nanometersized polymer hydrogels (nanogels) have attracted growing interest. By trapping proteins in a hydrated polymernetwork, nanogels minimize denaturation, simultaneously allowing a slow, continuous, and controlled release of the protein, ideally maintaining an effective concentration for the necessary period of time (Kim et al., 2009; Leonard et al., 2004; Murthy et al., 2002, 2003). Nanocarriers enable localized and specific targeting to their intended tissues or cells, thereby allowing the use of lower drug doses (Devalapally et al., 2007). The ideal protein delivery system should be able to enhance the protein solubility; allow its controlled and sustained release; improve biodistribution and targeting of the diseased tissue, in vivo (Tan et al., 2010). In addition, the nanocarrier must not compromise the bioactivity of the protein. On the other hand, binding/ trapping must be stable enough as to allow release only at the site of action, in a sustained, controlled way. Another critical 

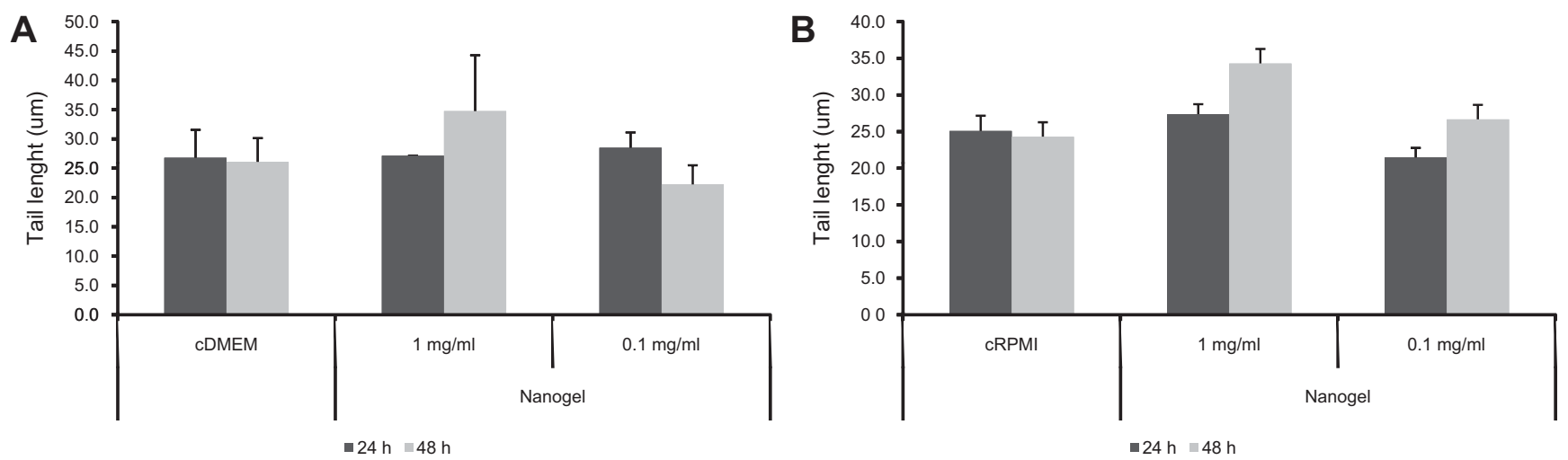

Figure 3. Mean TL values obtained for (A) mousse embryo $3 T 3$ fibroblasts and (B) BMDM.

impediment of cytokine therapy is the systemic adverse effects that can arise from the administration of high doses of cytokines. Hence, a delivery system that could enable a slow-release in vivo of a given cytokine may improve treatment, avoiding unwanted side-effects whereas improving therapeutic efficacy.

The rIL-10 incorporation by the nanogel suspension was described in a previous work (Carvalho et al., 2010), where it has been shown that a part of the encapsulated cytokine may be displaced by adding FBS to the colloidal suspension. There, it was also shown that the nanogel significantly stabilizes rIL-10, as evaluated by circular dichroism. However, denaturation of the cytokine still proceeds, even when complexed in the nanogel. rIL-10 is a very unstable protein with a predicted half-life of $4.4 \pm 0.7$ days, at $37^{\circ} \mathrm{C}$ in PBS, based on the evaluation of the mean residual ellipticity $(\theta)$ variation, at $222 \mathrm{~nm}$ (Carvalho et al., 2010). Probably, the release rate is dependent on the properties of the protein incorporated in the dextrin nanogel. Properties such as hydrophobicity, long-term stability and binding affinity can condition the incorporation and the release profile from (nano)hydrogels (Lee and Mooney, 2001; Lee and Yuk, 2007). This possibility will be exploited in forthcoming work using other bioactive proteins.

Indeed, a protein release system based on cholesterolbearing pullulan (CHP)-based nanogels (a nanogel similar to the one used in this work) for interleukin-12 (IL-12) was described recently (Hasegawa et al., 2009; Shimizu et al., 2008). IL-12 is an immunostimulatory cytokine that can suppress not only tumor growth and metastasis, but also infection and allergy. However, as for IL-10, it is difficult to maintain its plasma concentration at an effective level due to its short half-life in vivo. The CHP-based nanogels effectively incorporated IL-12 and maintained relatively high serum IL-12 levels in plasma after sc injection in mice for $12-24 \mathrm{~h}$. Additionally, tumor growth was successfully inhibited by weekly administrations of CHP/IL-12 complex. Later on, the same group (Hasegawa et al., 2009) prepared raspberry-like assembled nanogels (A-CHPNG) by crosslinking an acrylate group-modified cholesterol-bearing pullulan nanogel with thiol group-modified poly(ethylene glycol) (PEGSH). They showed that, even in the presence of a high concentration of BSA $(50 \mathrm{mg} / \mathrm{mL})$, A-CHPNG did not release IL-12 for at least $72 \mathrm{~h}$. As with the nanogel/rIL-10 complex, the IL-12 release is driven mainly by an exchange mechanism between IL-12 and BSA proteins and this exchange seem to be minimized by PEG chain which offer a structural stability and a protein-repellent property. This modification also allowed the maintenance of high plasma IL-12 levels for $72 \mathrm{~h}$.

A similar approach was attempted in this work using the nanogel/rIL-10 complex. In vivo kinetics of rIL-10 release was examined by administrating nanogel/rIL-10 into mice. Figure 4 illustrates the levels of IL-10 measured in the sera after administration of rIL-10 and nanogel/rIL-10.

After a sc injection with a free rIL-10 solution, the IL-10 concentration in the sera peaked at $1 \mathrm{~h}$, followed by a rapid decrease. In contrast, serum IL-10 levels remained relatively constant in the nanogel/rIL-10 treated mice (about 13\% of the concentration observed using free IL-10, $1 \mathrm{~h}$ after administration). It is noteworthy that a sc injection with nanogel/rIL-10 complex resulted in a sustained-release in vivo of the cytokine, whereas the administration of free rIL10 solution resulted in a rapid decrease of serum IL-10 levels.

However, it is noticeable that the release of the protein from the nanogel occurs to a limited extent and although a lower initial concentration of rIL-10 was expected when using the nanogel formulation, the aimed protein release over a wide time frame was not observed. Interestingly, it is possible to observe that while a quick concentration reduction occurs over time in the case of the free protein administration, the nanogel formulation allows a more constant concentration to be obtained, a highly desirable feature. However, the time frame of the observed release is still limited. This effect is likely due to the instability of the cytokine. We suppose that a strong interaction of the 


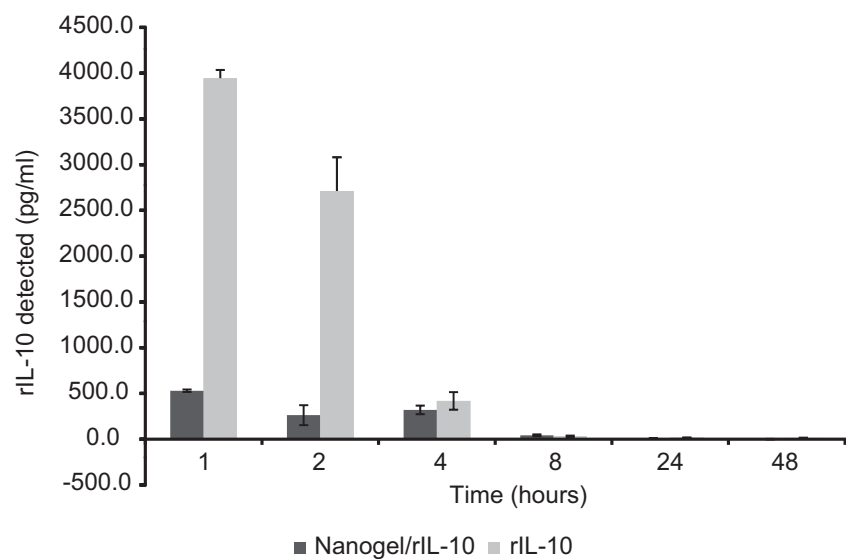

Figure 4. Serum concentrations of IL-10, evaluated by ELISA, after sc administration of soluble rIL-10 $(2.5 \mu \mathrm{g} /$ mouse $)$ or nanogel/rlL-10 $(1 \mathrm{mg} / \mathrm{mouse}$ nanogel, $2.5 \mu \mathrm{g} /$ mouse rIL-10). Shown are means \pm SD of IL-10 concentrations $(n=3)$.

cytokine may occur, likely involving a denatured fraction of rIL-10 and the hydrophobic domains inside the nanogel, as observed previously, leading to the incomplete release of the cytokine. Other proteins-more stable-may perform better.

Endotoxin from Gram-negative bacteria is a major causative agent of septic shock pathogenesis, and injection of LPS is a widely used experimental model of systemic inflammation (Gerard et al., 1993; Howard et al., 1993; Leon et al., 1999; Tang et al., 2010). The toxic effects of LPS are mostly related to macrophage activation leading to the release of multiple inflammatory mediators, as TNF- $\alpha$ and/ or IL-1. Previously, we demonstrated that rIL-10 as well as the complex nanogel/rIL-10, efficiently blocked the in vitro production of TNF- $\alpha$ by LPS-activated BMDMs (Carvalho et al., 2010). So, rIL-10 might be an efficient agent to diminish LPS toxicity in vivo.

To assess the in vivo effects of rIL-10 and nanogel/rIL-10 administration on LPS-induced TNF- $\alpha$ release, rIL-10, nanogel/rIL-10 complex and nanogel were given i.p. to C57BL/6 mice $30 \mathrm{~min}$ before the i.p. administration of $100 \mu \mathrm{g}$ LPS. Blood samples were taken 1.5 and $6 \mathrm{~h}$ after LPS challenge and serum TNF- $\alpha$ quantified by ELISA (Fig. 5). As controls, mice were also pretreated with PBS (with and without LPS challenge).

Sera from blood collected $1.5 \mathrm{~h}$ after LPS challenge indicates a substantial reduction in circulating TNF- $\alpha$ in animals receiving rIL-10 and nanogel/rIL-10 prior to LPS administration, comparing to animals receiving the nanogel or PBS. The inhibition of circulating TNF- $\alpha$ is directly related to the protection of mice from lethal endotoxemia (Tang et al., 2010; Wan et al., 2006), an effect that could be observed both with soluble and the nanogel/rIL-10 complex, contributing to the protection against lethal endotoxemia by inducing the suppression of TNF- $\alpha$.

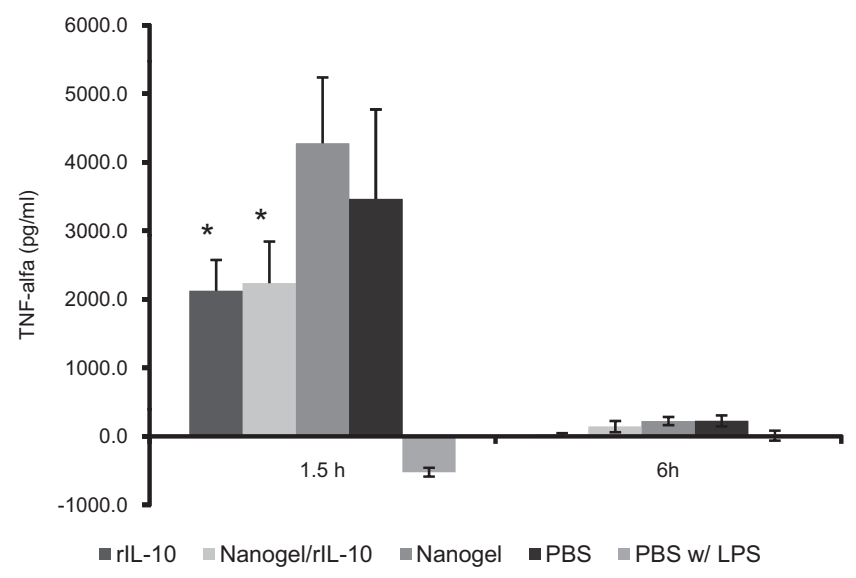

Figure 5. Serum concentrations of TNF- $\alpha$ induced by LPS challenge, detected after $30 \mathrm{~min}$ upon i.p. administration of soluble $\mathrm{rlL}-10(2.5 \mu \mathrm{g} / \mathrm{mouse})$, nanogel $/ \mathrm{rlL}-10$ (1 mg/mouse nanogel, $2.5 \mu \mathrm{g} / \mathrm{mouse} \mathrm{rlL}-10)$, and nanogel (1 mg/mouse). As controls, mice were pretreated with PBS and challenged (PBS) or not (PBS w/LPS) with LPS. TNF- $\alpha$ was quantified by ELISA and shown are means \pm SD of TNF- $\alpha$ concentrations $(n=4) .{ }^{*} P<0.05$ compared to TNF- $\alpha$ values obtained with PBS after LPS challenge.

Despite the incomplete release of rIL-10 from the complex nanogel/rIL-10, it is noticeable that the available protein is capable to efficiently diminish TNF- $\alpha$ production to levels achieved with the soluble protein. Therefore, it can be assumed that the rIL-10 is been released from the complex nanogel/rIL-10 in biologically significant amounts. Further characterization of the rIL-10 - nanogel interation is required to better evaluate the potential of this formulation. The nanogels may perform more effectively with other proteins (unpublished ongoing work).

\section{Conclusions}

The therapeutic potential of many pharmaceutical proteins could profit considerably from the availability of controlled released systems for the constant release of the intact biologically active protein. IL-10 has potential application in various medical fields, such as in acute inflammatory diseases, so it is important to develop IL-10 release systems, in order to prevent IL-10 denaturation and to enable a slow controlled release.

We have previously demonstrated that the dextrin nanogel enhances rIL-10 stability and allows the release of biologically active rIL-10 in vitro (Carvalho et al., 2010). This work further shows that the dextrin nanogel is biocompatible and that is able to release rIL-10 in biologically relevant amounts over $4 \mathrm{~h}$, after sc administration in mice. It also shown that rIL-10, complexed with the nanogel or not, is able to reduce TNF- $\alpha$ production after LPS challenge in vivo.

The major limitation to this system seems to lie on the strong interaction of rIL-10 with the nanogel, due to fast denaturation of the cytokine in spite of the stabilizing effect 
of the nanogel. The use of additives and further stabilization of rIL-10 is expected to improve the performance of these formulations, allowing a controlled release over a long period of time. Dextrin nanogels are thus a promising system for protein delivery and more sophisticated formulations with targeting ability are being developed.

Vera Carvalho was supported by the grant SFRH/BD/27359/2006 from Fundação para a Ciência e Tecnologia (FCT), Portugal. This study was financially supported by FCT through the project PTDC/ BIO/67160/2006 and by SUDOE-FEDERIMMUNONETSOE1/P1/ E014 grant.

\section{References}

Anderson D, Plewa MJ. 1998. The International Comet Assay Workshop. Mutagenesis 13(1):67-73

Anderson D, Yu TW, McGregor DB. 1998. Comet assay responses as indicators of carcinogen exposure. Mutagenesis 13(6):539-555.

Asadullah K, Sterry W, Volk HD. 2003. Interleukin-10 therapy-review of a new approach. Pharmacol Rev 55(2):241-269.

Barnes CA, Elsaesser A, Arkusz J, Smok A, Palus J, Lesniak A, Salvati A, Hanrahan JP, de Jong WH, Dziubaltowska E, Stepnik M, Rydzynski K, McKerr G, Lynch I, Dawson KA, Howard CV. 2008. Reproducible Comet assay of amorphous silica nanoparticles detects no genotoxicity. Nano Lett 8(9):3069-3074.

Berzofsky JA, Ahlers JD, Belyakov IM. 2001. Strategies for designing and optimizing new generation vaccines. Nat Rev Immunol 1(3):209-219.

Bogdan C, Vodovotz Y, Nathan C. 1991. Macrophage deactivation by interleukin 10. J Exp Med 174(6):1549-1555.

Branco MC, Schneider JP. 2009. Self-assembling materials for therapeutic delivery. Acta Biomater 5(3):817-831.

Brendler-Schwaab S, Hartmann A, Pfuhler S, Speit G. 2005. The in vivo comet assay: Use and status in genotoxicity testing. Mutagenesis 20(4):245-254.

Carvalho V, Castanheira P, Faria TQ, Goncalves C, Madureira P, Faro C, Domingues L, Brito RMM, Vilanova M, Gama FM. 2010. Biological activity of heterologous murine interleukin-10 and preliminary studies on the use of a dextrin nanogel as a delivery system. Int J Pharm 400:234-242.

Chiellini EE, Chiellini F, Solaro R. 2006. Bioerodible polymeric nanoparticles for targeted delivery of proteic drugs. J Nanosci Nanotechnol 6(910):3040-3047.

Collins AR, Dobson VL, Dusinska M, Kennedy G, Stetina R. 1997. The comet assay: What can it really tell us? Mutat Res Fundam Mol Mech Mutagen 375(2):183-193.

Collins AR, Oscoz AA, Brunborg G, Gaivao I, Giovannelli L, Kruszewski M, Smith CC, Stetina R. 2008. The comet assay: Topical issues. Mutagenesis 23(3):143-151.

Costa S, Coelho P, Costa C, Silva S, Mayan O, Santos LS, Gaspar J, Teixeira JP. 2008. Genotoxic damage in pathology anatomy laboratory workers exposed to formaldehyde. Toxicology 252(1-3):40-48.

Creery WD, Diaz-Mitoma F, Filion L, Kumar A. 1996. Differential modulation of B7-1 and B7-2 isoform expression on human monocytes by cytokines which influence the development of $\mathrm{T}$ helper cell phenotype. Eur J Immunol 26(6):1273-1277.

de Waal Malefyt R, Abrams J, Bennett B, Figdor CG, de Vries JE. 1991a Interleukin 10(IL-10) inhibits cytokine synthesis by human monocytes: An autoregulatory role of IL-10 produced by monocytes. J Exp Med 174(5):1209-1220.

de Waal Malefyt R, Haanen J, Spits H, Roncarolo MG, te Velde A, Figdor C, Johnson K, Kastelein R, Yssel H, de Vries JE. 1991b. Interleukin 10 (IL10) and viral IL-10 strongly reduce antigen-specific human $\mathrm{T}$ cell proliferation by diminishing the antigen-presenting capacity of mono- cytes via downregulation of class II major histocompatibility complex expression. J Exp Med 174(4):915-924.

Defrance T, Vanbervliet B, Briere F, Durand I, Rousset F, Banchereau J. 1992. Interleukin 10 and transforming growth factor beta cooperate to induce anti-CD40-activated naive human B cells to secrete immunoglobulin A. J Exp Med 175(3):671-682.

Devalapally H, Chakilam A, Amiji MM. 2007. Role of nanotechnology in pharmaceutical product development. J Pharm Sci 96(10):2547-2565.

Fairbairn DW, Olive PL, Oneill KL. 1995. The Comet Assay-a comprehensive review. Mutat Res Rev Genet Toxicol 339(1):37-59.

Fichthorn KA, Qin Y. 2006. Molecular-dynamics simulation of colloidal nanoparticle forces. Ind Eng Chem Res 45(16):5477-5481.

Fiorentino DF, Zlotnik A, Mosmann TR, Howard M, O'Garra A. 1991. IL10 inhibits cytokine production by activated macrophages. J Immunol 147(11):3815-3822.

Gazzinelli RT, Oswald IP, James SL, Sher A. 1992. IL-10 inhibits parasite killing and nitrogen oxide production by IFN-gamma-activated macrophages. J Immunol 148(6):1792-1796.

Gerard C, Bruyns C, Marchant A, Abramowicz D, Vandenabeele P, Delvaux A, Fiers W, Goldman M, Velu T. 1993. Interleukin 10 reduces the release of tumor necrosis factor and prevents lethality in experimental endotoxemia. J Exp Med 177(2):547-550.

Goncalves C, Gama FM. 2008. Characterization of the self-assembly process of hydrophobically modified dextrin. Eur Polym J 44(11):3529-3534.

Goncalves C, Martins JA, Gama FM. 2007. Self-assembled nanoparticles of dextrin substituted with hexadecanethiol. Biomacromolecules 8(2):392-398.

Goncalves C, Torrado E, Martins T, Pereira P, Pedrosa J, Gama M. 2010. Dextrin nanoparticles: Studies on the interaction with murine macrophages and blood clearance. Colloids Surf B-Biointerfaces 75(2):483-489.

Groux H, Bigler M, de Vries JE, Roncarolo MG. 1998. Inhibitory and stimulatory effects of IL-10 on human CD8+ T cells. J Immunol 160(7):3188-3193.

Haag R, Kratz F. 2006. Polymer therapeutics: Concepts and applications. Angew Chem Int Ed Engl 45(8):1198-1215.

Hasegawa U, Sawada S, Shimizu T, Kishida T, Otsuji E, Mazda O, Akiyoshi K. 2009. Raspberry-like assembly of cross-linked nanogels for protein delivery. J Control Release 140(3):312-317.

Howard M, Muchamuel T, Andrade S, Menon S. 1993. Interleukin 10 protects mice from lethal endotoxemia. J Exp Med 177(4):1205-1208.

Hreczuk-Hirst D, Chicco D, German L, Duncan R. 2001. Dextrins as potential carriers for drug targeting: Tailored rates of dextrin degradation by introduction of pendant groups. Int J Pharm 230(1-2):57-66.

Hubel K, Dale DC, Liles WC. 2002. Therapeutic use of cytokines to modulate phagocyte function for the treatment of infectious diseases: Current status of granulocyte colony-stimulating factor, granulocytemacrophage colony-stimulating factor, macrophage colony-stimulating factor, and interferon-gamma. J Infect Dis 185(10):1490-1501.

Kim S, Kim JH, Jeon O, Kwon IC, Park K. 2009. Engineered polymers for advanced drug delivery. Eur J Pharm Biopharm 71(3):420-430.

Lee KY, Mooney DJ. 2001. Hydrogels for tissue engineering. Chem Rev 101(7):1869-1879.

Lee KY, Yuk SH. 2007. Polymeric protein delivery systems. Prog Polym Sci 32(7):669-697.

Leon LR, Kozak W, Rudolph K, Kluger MJ. 1999. An antipyretic role for interleukin-10 in LPS fever in mice. Am J Physiol 276(1 Pt 2):R81-R89.

Leonard M, De Boisseson MR, Hubert P, Dalencon F, Dellacherie E. 2004. Hydrophobically modified alginate hydrogels as protein carriers with specific controlled release properties. J Control Release 98(3):395-405.

Lukyanov AN, Torchilin VP. 2004. Micelles from lipid derivatives of watersoluble polymers as delivery systems for poorly soluble drugs. Adv Drug Deliv Rev 56(9):1273-1289.

MacNeil IA, Suda T, Moore KW, Mosmann TR, Zlotnik A. 1990. IL-10, a novel growth cofactor for mature and immature T cells. J Immunol 145(12):4167-4173.

Miyamae Y, Iwasaki K, Kinae N, Tsuda S, Murakami M, Tanaka M, Sasaki YF. 1997. Detection of DNA lesions induced by chemical mutagens 
using the single-cell gel electrophoresis (Comet) assay. 2. Relationship between DNA migration and alkaline condition. Mutat Res Genet Toxicol Environ Mutagen 393(1-2):107-113.

Moore KW, de Waal Malefyt R, Coffman RL, O'Garra A. 2001. Interleukin10 and the interleukin-10 receptor. Annu Rev Immunol 19:683-765.

Mosmann T. 1983. Rapid colorimetric assay for cellular growth and survival: Application to proliferation and cytotoxicity assays. J Immunol Methods 65(1-2):55-63.

Murthy N, Thng YX, Schuck S, Xu MC, Frechet JM. 2002. A novel strategy for encapsulation and release of proteins: Hydrogels and microgels with acid-labile acetal cross-linkers. J Am Chem Soc 124(42):12398-12399.

Murthy N, Xu M, Schuck S, Kunisawa J, Shastri N, Frechet JM. 2003. A macromolecular delivery vehicle for protein-based vaccines: Aciddegradable protein-loaded microgels. Proc Natl Acad Sci USA 100(9):4995-5000.

Nair LS, Laurencin CT. 2006. Polymers as biomaterials for tissue engineering and controlled drug delivery. Tissue Eng I: Scaffold Syst Tissue Eng 102:47-90.

Nayak S, Lyon LA. 2005. Soft nanotechnology with soft nanoparticles. Angew Chem Int Ed Engl 44(47):7686-7708.

Pestka S, Krause CD, Sarkar D, Walter MR, Shi Y, Fisher PB. 2004. Interleukin-10 and related cytokines and receptors. Annu Rev Immunol 22:929-979.

Pullerits T. 2002. Cytokine modulation for anti-allergic treatment. Curr Pharm Des 8(20):1845-1853.

Shimizu T, Kishida T, Hasegawa U, Ueda Y, Imanishi J, Yamagishi H, Akiyoshi K, Otsuji E, Mazda O. 2008. Nanogel DDS enables sustained release of IL-12 for tumor immunotherapy. Biochem Biophys Res Commun 367(2):330-335.
Singh NP, Mccoy MT, Tice RR, Schneider EL. 1988. A simple technique for quantitation of low-levels of DNA damage in individual cells. Exp Cell Res 175(1):184-191.

Tan ML, Choong PF, Dass CR. 2010. Recent developments in liposomes, microparticles and nanoparticles for protein and peptide drug delivery. Peptides 31(1):184-193.

Tang Y, Li B, Wang N, Xie Y, Wang L, Yuan Q, Zhang F, Qin J, Peng Z, Ning W, Wang L, Hu G, Li J, Tao L. 2010. Fluorofenidone protects mice from lethal endotoxemia through the inhibition of TNF-alpha and IL-1beta release. Int Immunopharmacol 10(5):580-583.

Tice RR, Agurell E, Anderson D, Burlinson B, Hartmann A, Kobayashi H, Miyamae Y, Rojas E, Ryu JC, Sasaki YF. 2000. Single cell gel/comet assay: Guidelines for in vitro and in vivo genetic toxicology testing. Environ Mol Mutagen 35(3):206-221.

Tushinski RJ, Oliver IT, Guilbert LJ, Tynan PW, Warner JR, Stanley ER. 1982. Survival of mononuclear phagocytes depends on a lineagespecific growth factor that the differentiated cells selectively destroy. Cell 28(1):71-81.

Wan JM, Sit WH, Lee CL, Fu KH, Chan DK. 2006. Protection of lethal toxicity of endotoxin by salvia miltiorrhiza BUNGE is via reduction in tumor necrosis factor alpha release and liver injury. Int Immunopharmacol 6(5):750-758.

Willems F, Marchant A, Delville JP, Gerard C, Delvaux A, Velu T, de Boer M, Goldman M. 1994. Interleukin-10 inhibits B7 and intercellular adhesion molecule-1 expression on human monocytes. Eur J Immunol 24(4):1007-1009.

Zhang X, Goncalves R, Mosser DM. 2008. The isolation and characterization of murine macrophages. Curr Protoc Immunol 83:14.1.114.1.14. 